\title{
Sanya Osha and the Triple Discourse: Postcoloniality, Subjectivity, and Democratic Consensus
}

\section{RICHARD OBINNA IROANYA}

Thabo Mbeki African Leadership Institute (TMALI), University of South Africa (iroanyr@unisa.ac.za; obinnarichard@yahoo.com)

This paper reviews Sanya Osha's latest book on Africa's postcolonial conditions, especially as it concerns democratic governance. The review considers the book as trans-disciplinary and focuses on its three sub-themes, namely, postmodernity, decolonization and globalization. The main arguments of the author on these sub-themes are highlighted and briefly discussed. While the review finds the author's overall discourse interesting and insightful to the understanding of African postcolonial conditions, it nevertheless raises concerns on some of the issues the author discussed such as criticisms of Acbille Mbembe and others.

Keywords: Colonialism; democracy; informality; globalization; modernity; post-colonialism; postmodernity; subjectivity

SANYA OSHA, African Postcolonial Modernity, Informal Subjectivity and Democratic Consensus, Palgrave

Macmillan: New York, 262 pages.

\section{$1 \quad$ Structure and Main Themes}

Osha's work is an interesting discourse about Africa's postcolonial conditions. The work is structured into seven chapters that address sub-themes of modernity, decolonization, and globalization within a central theme of African democracy.

Revisiting the idea of democracy in its Greek form enables the author to show how far African democracy has digressed. It also calls attention to aspects of Greek democracy such as the separation of public and private realms which are still relevant to the present and which need to be incorporated into Africa's democratic practices. Osha discusses, for example, the need to revise Africa's democratic practices in such a way that private and public realms become separated. As the title indicates, the book's central theme focuses on the serious impact of modernism, colonialism, and post-colonialism on African social, economic and governance systems. The book acknowledges that Africa's trajectories through modernism, colonialism, and post-colonialism have never been smooth but bumpy and unpredictable. The author considers whether unfortunate events such as civil wars, genocides, famines, and squalor have been obstacles to Africa's march towards development.

Categories such as modernism, colonialism and postcolonialism determine Africa's position in a global system characterized by the political, economic, social, and technological domination of some states over others. Therefore, an explicit concern with Africa's subordinated connection to the global system permeates the book. The continent's marginal position within the global economic, social and technological systems is blamed for most of its precarious conditions. However, the interruption of Africa's historical 
development by modernity, colonialism and post-colonialism is not entirely perceived in a bad light. Instead the author posits that such interruptions provide evidence of Africa's promise, vigour and dynamism.

The first sub-theme of the book which the author addresses is modernity and like each of the others, it is portrayed as a predicament for Africa. Modernity stems from a combination of European notions of accomplishment of the Enlightenment; legacies of Voltaire, Diderot, and Rousseau; faith in the promise of science and technology; radical discontinuity with medievalism and acceptance of the rationalism of Kant, Hume, and J.S. Mill as well as the espousal of a politically appropriate sense of progressiveness. Importantly, African modernity have never been the same as Euro-modernity (203). African modernities are a "combination of aspects of Euro-modernity, secularism, Christian cosmology, Islamism; indigenous, African systems of knowledge; and other syncretic cultural forms that lie outside these categories" (ibid.).

He particularly notes the constant struggle between formal and informal institutions in the African context. The complex intermingling of the formal and informal, public and private in governance practices compels the author to conclude that the line between what is formal and what is informal is often blurred in the African context. The reader is informed that African subjectivities manifest in spaces regarding "what human kind had been, what it is presently, and what it could become" (Preface). Africans cannot always engage with those modern institutions that arbitrate human kind's past, present, and future. The book reflects on Africa's dilemma regarding the need to escape from narrow confines of modern institutions and to engage with them.

The second problem identified in the book is decolonization. Whereas decolonization is supposed to be emancipatory, it has instead functioned as a "politics of ethnicity, race, territoriality, citizenship, and belonging" (204) with serious consequences for nationhood in Africa. This is a result of socio-political instability in almost all African states. The author appears much concerned with the issue of nation-building in his treatment of decolonization. He characterizes decolonization as Africans' "first self-directed attempt at nation-building" (ibid.) which does not seem to have been realized. As such, he discounts claims that decolonization means the same as political liberation. This is a controversial and radical proposition but when one reads further, justification for it is presented (ibid.). Accordingly, while European colonialism created modern African nation-states, African decolonization has only partially succeeded in building nations out of multinational states in Africa. Post-colonial African states have not been able to successfully "consolidate the features of artificially imposed political geographies" (ibid.). Reality rather than rhetoric of associating decolonization with political liberation supports this claim. On why decolonization has failed to lift post-colonial African states, two reasons are provided. First, Africa is said to suffer from exhaustion because slavery and colonization have tasked much of her energy. Second, Africa is said to be pursuing decolonization "without adequate resources in terms of personnel and institutions" (ibid.).

In the same vein, globalization is addressed as the third category of Africa's predicament. The process of globalization is described in two ways. First, globalization is "the metaphor of virtualization; flows and global connectedness and interdependencies" (ibid.). Second, globalization is also considered as "a radical acceleration of modernity in the better positioned regions of the world" (ibid.). A contention is therefore made that like the processes of modernity and decolonization, Africa has not decided where it fits in the process of globalization. The changing notions of sovereignty, territoriality, citizenship, and belonging in the African context are directly linked to conditions of contemporary globalization. Osha expresses fear that African institutions are not flexible and sufficiently responsive to adverse impacts of globalization on Africa (205). There seems to be a suggestion that for Africa to fit within the process of globalization without structural subordination, it has to address its vacuum of flexible and responsive institutions as well as "the dilemmas and difficulties posed by truncated projects and processes of modernity and nation-building" (ibid.).

Osha's examination of the three categories or processes of predicament-modernity, decolonization and globalization-obliges the conclusion that "there is a crisis at the heart of the project of modernity itself" (203). The core of the problem with modernity in relation to Africa is its "tendency toward universalism [...] a universalization of its promise, aspirations, and limitations" and "an undefined logic of 
the imperial" (ibid.) or domination. The author does not seem to believe that globalization is bad in its entirety. Thus, there is an inference that if globalization does not involve the imperial pursuits of its pushers, it does have the potential of bringing about "cosmopolitan inclusiveness," to discount "cultural elitism," and promote "a multicultural cosmos" (ibid.).

Despite aspects of universalization that are promising, Africans are cautioned against the type of global ethics being pursued by major powers. It is a form of universalization that has little patience with Africa. Specifically, the origin of the impatient form of universalization is traceable to the events of $9 / 11$ in the United States. The tragic events of 9/11, it is argued, provided an opportunity to redefine the universal or a new ethics of the universal. Universalization had been an ongoing project with a more subtle and cautious strategy. But that strategy radically changed after the events of $9 / 11$, and caution, pretence and subtleness were replaced by a more visible strategy of "criminalization of manifestations of cultural differences, and entrenchment of previously latent fundamentalism" (202). In other words, the new strategy of universalization negates and devalues the "exigencies of the politics of the particular" (201). Fears are therefore expressed that this new ethics of the universal have become "imperial" with serious consequences for "African territoriality $[\ldots]$ sovereignty $[\ldots]$ citizenship, and belonging without the participation of Africans as active agents" (202).

\section{Resolving Africa's Predicaments}

The author has not only examined problems besetting Africa but has also proposed ways of resolving its contradictions. Thus, he emphasizes the need for Africa to reconceptualize the three main categories of its predicament because it is only in so doing that it can define what to do with these processes. The continent cannot leave "the labour of conceptualizing these existential dilemmas to non-Africans alone" (208). It is necessary to "avoid the dialectics of fear and impatience, which the contemporary moment seems to encourage" (206). Similarly, Africans are called to "also resist the totalitarianism of the universal" and "resolve problems with decolonization and the general notion of nation-building" (ibid.). In other words, decolonization should not take the coloration of ethnicity and territoriality but be used to truly emancipate Africa from the dictates of universalism. To benefit from these processes, Africa needs to resolve the "tussle between the tradition and modernity, and the tensions between the particular and the universal" (207). Africans are encouraged to see Africa's problems as "part of the struggle for self-invention" (208). Africans are also encouraged not to give up on the struggles for self-invention and the development of institutions. This is because "transplanted institutions and traditions have repeatedly failed" on the continent (ibid.).

\section{Conclusion}

It is not easy to specifically classify African Postcolonial Modernity, Informal Subjectivity and Democratic Consensus within any specific academic field. Although it appears to have a strong philosophical grounding, one can still see historical, political, sociological and cultural influences within its school of critical discourse. Reading this book, one gets the impression that the author is deeply philosophical in style. Creative use of words and metaphors point towards deeper meanings of subjects under discussion and showcases the author as a linguist. The discussion of issues from historical perspectives places the book between the boundaries of history and philosophy following in the steps of Michel Foucault, who employs historical evidence to make philosophical arguments. However, knowing what historical, social, economic, political, cultural and religious examples to cite, and how, where and when to introduce them in the discourses sets the author apart as a multi or trans-disciplinary scholar. Thus, the reader is introduced to anthropology through ethnographic examples and employment of terms such as "liminality"; history through narratives of 
historical events; sociology through social theories and issues, and politics through the treatment of governmentality.

Much reference to western philosophies and epistemologies in discussing postcolonial Africa, tends to suggest that the author believes in the universality of epistemology although there are criticisms of certain forms of it such as those that followed 9/11. A commitment to the universality of knowledge is portrayed through obvious demonstration of the acquisition of other knowledge systems beyond Africa. For example, the use of the German word Weltanschaunngen, which means 'world views,' demonstrates that knowledge from outside Africa can be adopted, reshaped and integrated into the African context. This sharply undermines the author's criticism of Achille Mbembe. It also contradicts certain afrocentricity and decoloniality discourses which tend to discount western epistemologies and their applicability or relevance to postcolonial African conditions.

While a combination of notions of the Enlightenment; legacies of philosophers; rejection of medievalism and belief in science and technology and political progressiveness, led to Euro-modernity, no justification is provided as to why a combination of similar sources resulted into 'African-modernities' instead of 'Afro-modernity.' We are also told that Islam played a significant role in fashioning African modernities, but no role is ascribed to the religion in the making of Euro-modernity. One wonders if this is not an outright oversight as Islamic influence is well documented in European history. Religiously, the crusade bears testimony to Islamic influence. One further wonders if Islam has not played any significant role in the development of the West's scientific tradition to warrant mention by the author.

Furthermore, no form of claim of exceptionalism in human experiences is made for Africa. By not making this claim for Africa, the author has strengthened the belief in similarity of human experiences and development globally. If this reading is correct, the author is not wrong in seeing that countries in Europe (medieval Europe), Asia, and South America, for example, at different times in history experienced slavery and colonialism similar to Africans. Therefore, analyzing African conditions purely through these categories is grossly reductive. Overall, it is an interesting work, which contributes to knowledge regarding issues of democracy, economy, social conditions and globalism in the African context.

Richard Iroanya is a postdoctoral research fellow at the Thabo Mbeki African Leadership Institute, University of South Africa. Previously, he was a senior researcher at the African Institute of South Africa in Pretoria. Currently, he is working on a book on human trafficking and security in Africa. Among his latest publications are: "Human Trafficking with Specific Reference to South African and Mozambican Counter-Trafficking Legislation”, Southern African Journal of Criminology 27, no. 2 (2014); and with Aondowase Nyam "Political Conflict in Africa: The Implications of Electoral Violence for Human and National Security in Nigeria," Democratization of Africa: Dynamics and Trends, ed. Alexius Amtaika (Texas, Austin: Pan African University Press, 2016). 